\title{
PERILAKU MASYARAKAT TEPI SUNGAI DALAM MASALAH SAMPAH DISEKITAR SUNGAI
}

\author{
Muhammad Akmal Al Farizi \\ Universitas Lambung Mangkurat, Fakultas Keguruan Dan Ilmu Pendidikan, \\ Program Studi Pendidikan IPS \\ Banjarmasin \\ e-mail: 2010128310003@mhs.u1m.ac.id
}

\begin{abstract}
Abstrak
Timbulnya sampah dari hari ke hari cenderung meningkat dan bervariasi, sehingga seringkali sampah menjadi masalah karena pengelolaan yang belum baik. Pola pikir, pola sikap, dan pola tindak yang masih keliru terhadap sampah telah menimbulkan permasalahan sosial, lingkungan, dan kesehatan. Permasalahan lingkungan antara lain terjadinya kerusakan dalam sistem air, sehingga terjadi pencemaran air yang disebabkan aktivitas membuang sampah ke badan air. Ditinjau dari segi kualitas, kondisi perairan sungai yang berada di kota besar di Indonesia semakin menurun. Menurunnya kondisi tersebut salah satunya disebabkan karena pembuangan sampah ke sungai. Kegiatan pembuangan sampah ke sungai umumnya dilakukan oleh penduduk yang tinggal dan/atau beraktivitas di bantaran sungai. Oleh karena itu, prioritas untuk mengurangi jumlah sampah yang dibuang ke sungai lebih ditekankan kepada masyarakat yang tinggal dan/atau beraktivitas di dekat sungai. Upaya pengendalian pencemaran sungai yang diakibatkan oleh sampah masih terbatas dan diperparah dengan rendahnya kesadaran masyarakat dalam menjaga lingkungannya serta kurangnya penegakan hukum bagi pelanggar pencemaran lingkungan. Oleh karena itu, diperlukan pendekatan yang komprehensif dan holistik bagi pengendalian pencemaran sungai yang diakibatkan oleh sampah, agar dapat dipertahankan kualitas lingkungan perairan yang baik. Pemerintah hendaknya mengeluarkan kebijakan yang pada dasarnya merangsang penduduk untuk melakukan pengelolaan sampah dengan pendekatan 3R (Reduce, Reuse dan Recycle).
\end{abstract}

Kata kunci: (kehidupan, lingkungan, masyarakat sungai, sampah)

\section{Pendahuluan}

Sungai ialah merupakan sumber air yang banyak memiliki fungsi bagi seluruh manusia. Mengingat pentingnya manfaat sungai terhadap kebutuhan seluruh makhluk hidup maka diperlukannya pelestarian sungai ( Muhjad, 2015).

Green (2006), dalam Notoatmodjo, 2008 mengembangkan bahwa faktor faktor yang mempengaruhi perilaku adalah sebagai berikut: 
1. Faktor prediposisi (Predisposing factor)Seperti kebiasaan masyarakat membuang sampah sembarang tempat, pengetahuanmasyarakat tentang sampah dan pengaruhnya terhadap lingkungan.

2. Faktor yang memudahkan (Enebling factor)Seperti ketersediaan fasilitas dan lain sebagainya.

3. Faktor yang memperkuat (Reinforcing factor)Seperti sikap dan prilaku petugas kesehatan (Notoatmojo, 2008)

Kawasan tepi sungai merupakan kawasan tempat bertemunya daratan dan air sungai. Kawasan yang dimaksud merupakan kawasan dinamis dan unik dari suatu kota, dan sangat strategis karena mudah dicapai dari daratan maupun sungai. Kawasan tepi sungai difungsikan antara lain untuk perdagangan, rekreasi, perkantoran,, pelabuhan, maupun perumahan. (Lestari, 2012).

Sungai merupakan aliran air yang besar dan memanjang yang mengalir secara terus menerus dari hulu (sumber) menuju hilir ( muara). Suwondo, 2004 memberi pengertian bahwa sungai merupakan suatu bentuk ekosistem aquatik yang mempunyai peran penting dalam daur hidrologi dan berfungsi sebagai daerah tangkapan air (catchment area) bagi daerah sekitarnya, sehingga kondisi suatu sungai sangat dipengaruhi oleh karakteristik yang dimiliki oleh lingkungan sekitarnya. Perilaku manusia merupakan penyebab paling besar terhadap kerusakan lingkungan. Ketidakpedulian penduduk bumi terhadap bencana. Perilaku tersebut kemungkinan dipengaruhi oleh beberapa faktor yang mempermudah, yaitu: pendidikan, pendapatan, pengatahuan, kesadaran, dan faktor sosial masyarakat, serta faktor pendukung, yaitu: jarak, ketersediaan sarana TPS, ketersediaan pelayanan pengangkutan sampah, biaya pelayanan pengangkutan sampah, dan budaya masyarakat (Soekidjo, 2003).

Pencemaran air sungai akibat pembuangan sampah membawa dampak negatif pada kesehatan manusia, terutama dengan meningkatnya penyakit diare serta biaya pengolahan air baku untuk air minum yang terus meningkat. Bahkan seringkali terjadi, terutama pada musim kemarau, kualitas air baku sudah tercemar berat akibatnya sulit diolah menjadi air yang layak diminum, sehingga bahan baku air minum harus didatangkan dari sumber yang lain (Susilowati, 2004).

Dengan perilaku masyarakat yang kurang sadar akan masalah yang terjadi di tepi sungai. Akibat dari perilaku masyarakat tersebut akan berdampak sangat parah bagi lingkungan sekitar serta berbagai macam akibat yang dirasakan. Mereka tidak menghiraukan membuang sampah dapat mengakibatkan hal-hal yang serius. Tujuan dari artikel ini yaitu mengetahui faktor dari 
perilaku masyarakat tersebut, cara menanggapi hal yang terjadi, serta pendekatan yang bisa mengubah perilaku masyarakat tepi sungai itu.

\section{Metode}

Metode yang digunakan dalam penelitian ini yaitu dengan menggunakan metode deskripsi dengan melalui analisis kuantitatif. Metode ini dengan cara mengumpulkan jurnal jurnal yang berbeda lalu di analisis data kuantitatif dengan tujuan menguji hipotesis yang telah di tetapkan.

\section{Pembahasan}

Dalam tatanan kehidupan manusia, air sangat mempunyai peranan penting yang sangat bermanfaat bagi kehidupan manusia. Kegiatan manusia sehari-hari juga tidak terlepas dari air terutama sungai sebagai sumber paling banyak air. Untuk mendapatkan air yang bermutu tentunya manusia harus menyadari dampak pencemaran air disungai akibat pembuangan sampah sembarangan. Perilaku masyarakat membuang sampah di daerah aliran sungai sangat bertentangan dengan prinsip perilaku pro- lingkungan dan menyinggung nilai-nilai dari keterkaitan lain yang menghormati bumi dengan mencegah pencemaran dan pemersatuan dengan alam.

Dari sudut pandang seseorang penyebab dari masalah lingkungan jelas berbeda - beda serta pemecahan permasalahan nya pun bermacam - macam, maka dari itu apabila pemecahan dari permasalahan tersebut tidak terpecahkan kehidupan di bumi akan sangat mengkhawatirkan. Hal ini di sebabkan karena adanya sumber daya alam menjadi penyedia sumber segala kebutuhan hidup manusia seperti penyedia udara, air, makanan, obat-obatan, estetika, dan lainnya. Pada umumnya di daerah perkotaan yang sedang berkembang akan mendapatkan masalah yang sama, yaitu seperti kebersihan lingkungan dikarenakan meningkatnya populasi manusia yang beriringan dengan meningkatnya populasi sampah.

Sampah merupakan sebuah ancaman yang serius di masyarakat. Karena itu pembuangan sampah sembarangan menyebabkan pencemaran lingkungan, terlebih lagi terhadap sungai. Banyaknya tersedia tempat sampah disetiap tempat tidak merubah perilaku masyarakt untuk membuang sampah ke sungai.

Kegiatan membuang sampah kesungai sudah menjadi tradisi warga tepi sungai, sehingga membuang sampah dan lainnya menjadi hal yang lumrah dan biasa saja. Kebiasaan tersebut terjadi hampir diseluruh masyarakat di Indonesia. Oleh sebab itu tidak jarang dikota kota besar yang dekat sungai terjadi penyumbatan sampah. Namun kondisi tersebut tidak di 
hiraukan masyarakat sekitar dan menganggap sebagai hal yang biasa tanpa memperdulikan hal tersebut dan para petugas terkait pun hanya membiarkan hal itu terjadi.

Kebiasaan warga yang membuang sampah ke sungai, salah satunya disebabkan kehidupan masyarakat Indonesia yang cenderung membelakangi sungai. Hal ini terlihat pada kota-kota besar yang ada di Indonesia. Sebagai contoh pada Sungai Ciliwung berada di DKI Jakarta, hampir semua rumah yang ada di bantaran sungai membelakangi sungai dan secara tidak langsung menepatkan sungai menjadi tempat pembuangan sampah sehingga sungai menjadi tidak bernilai apa-apa dan tidak perlu diperhatikan.

Banyak faktor yang mempengaruhi kualitas air sungai diantaranya perilaku masyarakat yang hidup di sepanjang aliran sungai, pencemaran dari hulu sungai akibat dari kegiatan yang ada baik itu dari warga masyarakat, kadang perusahaan perkebunan, ataupun dari kondisi alam itu sendiri.Baik buruknya kualitas air sungai tergantung dari perilaku warga dengan membuang sampah pada tempatnya, pembuangan limbah rumah tangga dapat berupa sisa sabun cuci pakaian dan peralatan rumah tangga, bangunan MCK yang pembuangannya langsung ke sungai dan kegiatan lainnya yang kesemuanya mempengaruhi.

Pada skala besar, sampah yang dibuang sembarangan menyebabkan di saluran air maupun sungai dan berujung mengotori laut. Berbagai macam sampah yang berada di lautan saat ini telah mengancam keselamatan makhluk laut, seperti bermacam jenis ikan yang sering dimakan manusia. Apabila terus menerus terjadi dapat mengancam salah satu sumber pemasukan manusia. Sampah yang dihasilkan dari berbagai kegiatan manusia kebanyakan bisa dibagi menjadi sampah organik dan anorganik. Sampah organik yaitu sampah yang dapat hancur dan berasal dari bahan-bahan yang bisa membusuk, seperti sisa makanan, kulit buah, dan batang sayur-sayuran. Sementara sampah anorganik adalah sampah yang tidak dapat terurai tetapi umumnya bisa didaur ulang, seperti yang terbuat dari plastik dan kaleng. Penyakit yang ditimbulkan dari sampah kepada manusia dapat melalui dua cara yaitu:

\section{Penularan langsung}

Sampah dibuang sembarangan bisa saja disentuh orang lain. anggota badan yang mengenai sampah itulah bakteri atau kuman dan parasit berpindah ke tubuh, sehingga menyebabkan berbagai penyakit.

\section{Penularan penyakit secara tidak langsung}

Penularan penyakit secara tidak langsung dapat terjadi melalui vektor atau hewan pembawa penyakit, seperti tikus, lalat, kecoa, nyamuk. Mereka bisa menjadi perantara masuknya bakteri, virus, cacing, dan banyak sekali berbagai penyakit lainnya. 


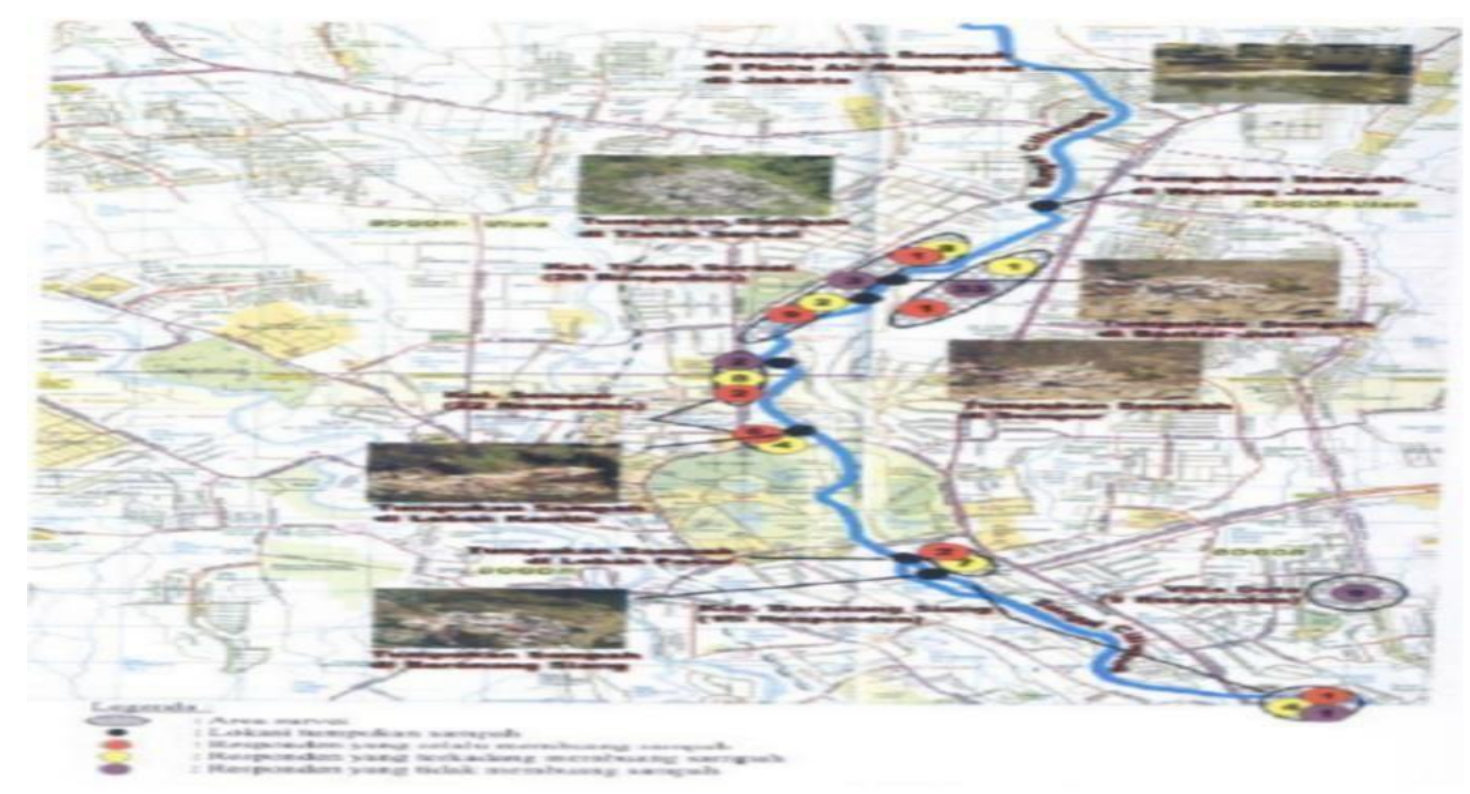

\section{Gambar 1. Peta Sungai Ciliwung}

Dimasa sekarang ini banyak masyarakat yang membuang sampah kesungai yang semakin meningkat, terutama jenis sampah anorganik. pembuangan sampah sembarangan ini diakibatkan banyaknya masyarakat yang tidak menjaga lingkungan dengan membuang sampah tidak pada tempatnya.

Jenis sampah anorganik yang paling umum di temukan di sungai adalah gelas plastik, kantong plastik dan bahan pembungkus makanan cepat saji, botol plastik serta kemasan plastik lainnya. jenis sampah anorganik ini apa umumnya di manfaatkan oleh para pemulung sampah sebagai bahan yang memberikan nilai ekonomi. Bukan hanya sampah jenis anorganik saja tetapi terdapat komponen sampah anorganik yang berupa kaleng atau logam. Adanya jenis sampah anorganik di perairan dapat menyebabkan terjadinya peningkatan jumlah kadar ion logam di dalam air. Sampah anorganik ini bersalah dari bekas kemasan logam seperti cat, minuman, serta wadah bekas lain yabg terbuat dari logam. Adanya sampah anorganik tersebut akan meningkatkan kadar logam berat, seperti timbal $(\mathrm{Pb})$, arsen $(\mathrm{As})$, kadmium $(\mathrm{Cd})$, merkuri $(\mathrm{Hg})$, nikel (Ni), kalsium (Ca), magnesium (Mg), dan lain-lain. Apabila ion logam yang berasal dari logam berat maupun yang bersifat racun seperti $\mathrm{Pb}, \mathrm{Cd}$ ataupun $\mathrm{Hg}$, maka air yang mengandung ion-ion logam tersebut akan berdampak bagi kesehatan manusia.

Kegiatan seperti memulung atau memungut sampah di sungai merupakan sebuah aktivitas memanfaatkan peluang untuk menciptakan nilai ekonomi dari sampah. Pemulung dan Pengumpul sampah merupakan salah satu dari sekian banyaknya orang yang berupaya untuk mengubah barang yang kurang bernilai ekonomis menjadi sebuah barang yang bernilai ekonomis. Di dalam kegiatan para pemulung sampah ini mereka mencoba untuk memilahkan sampah sampah yang layak agar dapat di gunakan serta di daur ulang.

Dengan adanya para pemulung sampah ini diharapkan dapat mengurangi jumlah sampah di sungai serta di lingkungan sekitar. Salah satu kegiatan yang di lakukan pemulung sampah yang dapat kita temui di DKI Jakarta yaitu sebuah aktivitas memulung sampah di 
sungai Ciliwung. Di tengah maraknya Industrialisasi serta hiruk pikuknya kehidupan perkotaan, aktivitas tersebut masih tetap berjalan. Keuntung yang di raup cukup besaruntuk para pemulung dan pengepul sampah tetap bertahan. Namun, tidak satupun warga yang hidup di sekitar sungai ciliwung yang tertarik menjadi pemulung atau pengepul sampah.

Sampah yang terbawa arus di sungai ternyata masih banyak yang memiliki nilai ekonomi. Di beberapa kawasan seperti muara sungai di Jakarta, banyak pemulung yang mengumpulkan sampah, terutama sampah plastik. Jumlah sampah plastik ternyata cukup banyak, karena warga DKI Jakarta tidak terbiasa memilah sampah dari sumbernya atau pada saat di rumah masing-masing. Usaha para pemulung itu bisa kita lihat, misalnya seperti di bawah jembatan Kali Krukut, tepatnya yang ada di Jalan Pluit Selatan, Penjaringan, Jakarta Utara. Dalam aktivitasnya, ketika ada barang-barang bekas seperti botol plastik, gelas plastik, piring plastik, dan sebagainya melayang di permukaan air, para pemulung tersebut segera memungutnya dengan alat bantu berupa batang bambu atau galah. Tak sekedar nilai ekonomis, aktivitas memungut sampah di sungai juga berperan didalam meningkatkan kesejahteraan hidup, bahkan banyak dari mereka yang menggantungkan hidupnya untuk memulung sampah. Di sisi lain para pemulung tersebut juga turut membantu dalam menyelesaikan masalah pencemaran lingkungan terutama yang diakibatkan oleh sampah.
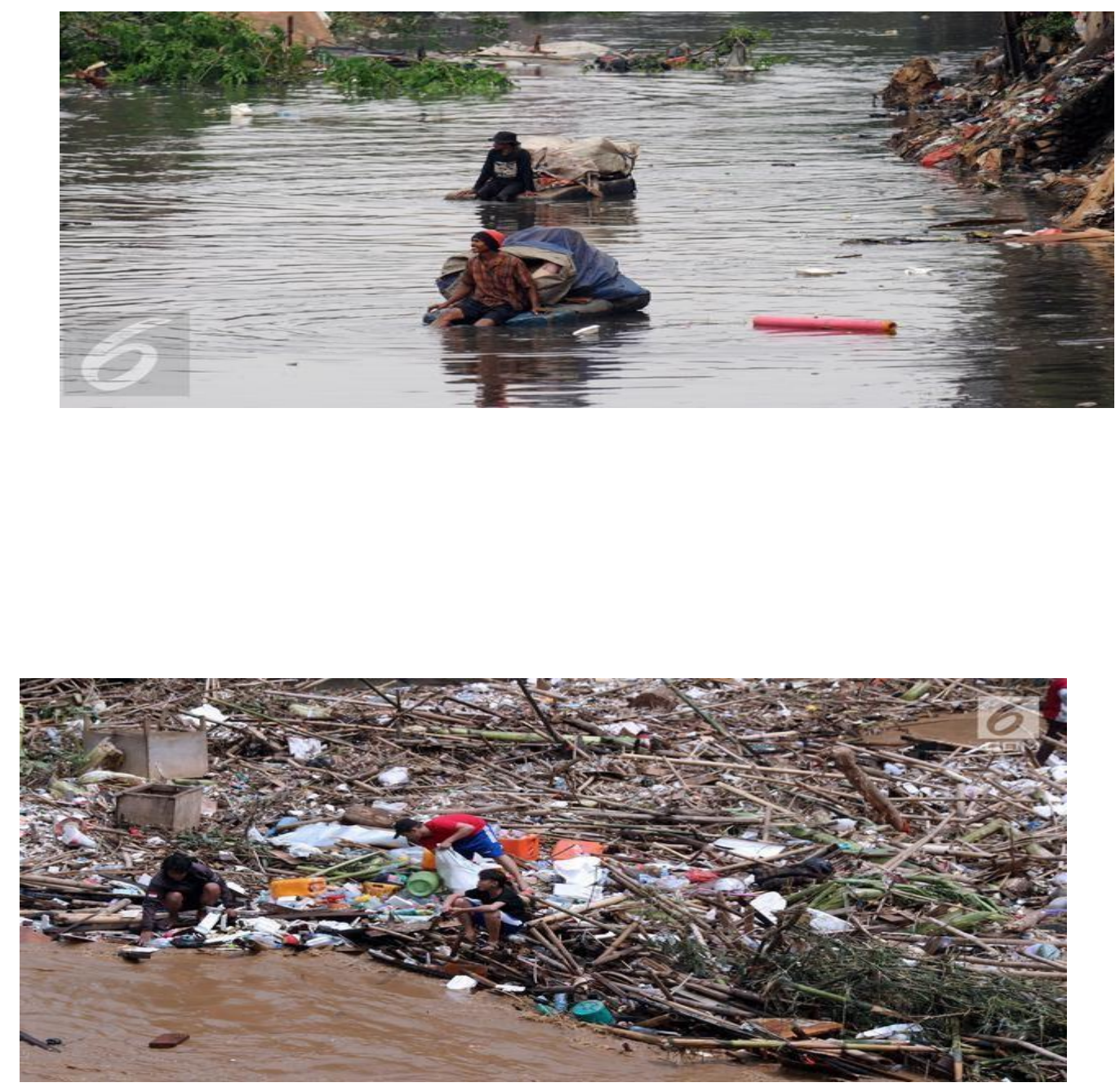

Gambar 2. Aktivitas Masyarakat Pemulung Memilah Sampah Di Sungai Ciliwung 
Pada prinsipnya ada 2 (dua) upaya untuk menanggulangi pencemaran, yaitu secara nonteknis dan secara teknis. Penanggulangan secara non-teknis melalui suatu usaha untuk mengurangi pencemaran lingkungan dengan cara menciptakan peraturan perundangan yang dapat merencanakan, mengatur dan mengawasi segala macam bentuk kegiatan industri dan teknologi sehingga tidak terjadi pencemaran. Peraturan perundangan ini hendaknya dapat memberikan gambaran secara jelas tentang kegiatan industri yang akan dilaksanakan, misalnya meliputi Analisis Mengenai Dampak Lingkungn, pengaturan dan pengawasan kegiatan dan menanamkan perilaku disiplin. Sedangkan penanggulangan secara teknis bersumber pada penanganan limbah secara benar termasuk perlakuan industri terhadap bahan buangannya, misalnya dengan mengubah proses, mengelola limbah atau menambah alat bantu yang dapat mengurangi pencemaran terhadap lingkungan.

Pengendalian dan penanggulangan pencemaran air di Indonesia telah diatur melalui Peraturan Pemerintah Nomor 82 tahun 2001 tentang Pengelolaan Kualitas dan Pengendalian Pencemaran Air. Secara umum hal ini meliputi pencemaran air baik oleh instansi ataupun noninstansi. Salah satu upaya serius yang telah dilakukan Pemerintah dalam pengendalian pencemaran air adalah melalui Program Kali Bersih . Program ini merupakan upaya untuk menurunkan beban limbah cair khususnya yang berasal dari kegiatan usaha skala menengah dan besar, serta dilakukan secara bertahap untuk mengendalikan beban pencemaran dari sumber-sumber lainnya. Program ini juga berusaha untuk menata permukiman di bantaran sungai dengan melibatkan masyarakat setempat (KLH, 2004). Akan tetapi, setelah sekian tahun harapan tersebut belum juga terwujud. Kondisi air sungai tetap keruh bahkan di beberapa sungai kondisi airnya hitam pekat, pembuangan sampah dan kotoran lainnya masih marak, pembangunan permukiman liar tetap marak, bahkan penyempitan alur sungai masih terus terjadi.

Sebenarnya pengendalian pencemaran air dapat dimulai dari diri sendiri. Dalam keseharian, warga dapat mengurangi pencemaran air dengan cara mengurangi jumlah timbulan sampah (reduce) setiap harinya. Selain itu, juga mendaur ulang (recycle) dan mendaur pakai (reuse) sampah tersebut. Teknologi dapat kita gunakan untuk mengatasi pencemaran air yang dikibatkan oleh sampah, antara lain dengan membangun fasilitas pengolahan sampah, termasuk air limbah (leachate) yang ramah lingkungan serta dioperasikan dan dipelihara dengan baik.

Dari segi kebijakan atau peraturan mengenai pencemaran air juga telah ada. Bila ingin benar-benar hal tersebut dapat dilaksanakan, maka penegakan hukum harus dilaksanakan pula. Pada akhirnya, banyak pilihan baik secara pribadi ataupun sosial (kolektif) yang harus ditetapkan, secara sadar maupun tidak, yang akan mempengaruhi tingkat pencemaran. Walaupun demikian, langkah pencegahan lebih efektif dan bijaksana. Melalui upaya pengendalian pencemaran ini diharapkan bahwa pencemaran akan berkurang dan kualitas hidup manusia akan lebih ditingkatkan, sehingga akan didapat sumber air yang aman, bersih dan sehat. 


\section{Simpulan}

Pembuangan sampah ke sungai umumnya dilakukan oleh masyarakat yang tinggal di bantaran sungai. Oleh karena itu, Pembuangan sampah kesungai dapat menyebabkan pencemaran pada sungai sehingga terbentuknya sendimen yang membuat sungai menjadi dangkal, kadar total suspended solid meningkat dan dissolve oksigen menurun. Otomatis kondisi ini mempengaruhi rantai makanan serta ekosistem yang ada di sungai. Bukan hanya itu limbah diterjen dari masyarakat yang mencuci baju di sungai juga menyebabkan tercemarnya air di sungai tersebut sehingga air tersebut bercampur dengan zat kimia yang terkandung dari deterjen tersebut. Bukan hanya itu warga yang tinggal di bantaran sungai itu pun membuang sampah ke sungai yang mengakibatkan sungai menjadi penuh dengan sampah. Oleh karena itu masyarkat diharuskan untuk memprioritaskan mengurangi sampah yang di buang kesungai serta kebijakn untuk membuang limbah limbah ke sungai. Rendahnya kesadaran dari masyarakat menyebabkan rusak nya ekosistem yang ada di sungai tersebut serta kurangnya penegakkan hukum bagi pelanggar aturan pencemaran lingkungan. Sebagai pemerintah juga hendaknya mengeluarkan kebijakan yang pada dasarnya digunakan untuk melakukan pengolahan sampah dengan pendekatan 3R (reduce, reuse, dan recycle). Strategi yang dapat kita lakukan untuk mengendalikan pencemaran air di sungai yaitu dengan cara membangun kerjasama dengan lintas sektor, yang di gunakan untuk pembangunan fasilitas secara swadaya atau pun bantuan dari pemerintah, sosialisasi dan pembinaan kepada masyarakat pembuatan regulasi serta komunitas masyarakat, pengawasan, serta penegakan hukum oleh aparatur pemerintahan. Maka dari itu diperlukan juga percontohan dari tokoh masyarakat dan pemerintah yang berfungsi untuk meningakatkan peran masyarakat untuk melestarikan lingkungan. 


\section{Daftar Pustaka}

Arisanty, D., Hastuti, K. P., Halawa, Y. A., Fitriani, D. N., \& Saifullah, S. (2020). Implementasi Pendidikan Lingkungan Hidup Pada Sekolah Dasar di Kalimantan Selatan Elochita, F. (2016). HUNIAN TEPI SUNGAI KARANGMUMUS DI SAMARINDA. eDimensi Arsitektur Petra, 4(2), 729-736.

Fakih, A. F., \& Sa'id, M. (2021, June). Perilaku Membuang Sampah di Sungai dan Problem Lingkungan: Pandangan Model Aktivasi Norma. In Seminar Nasional Psikologi UM (Vol. 1, No. 1, pp. 110-116).

Muhjad, M.H. (2015). Hukum lingkungan : sebuah pengantar untuk konteks Indonesia.Yogyakarta: GENTA. 
Penny, L., Bijaksana, U., Yunita, R., \& Itta, D. (2012). Kajian perilaku masyarakat membuang sampah di bantaran sungai martapura terhadap lingkungan perairan. EnviroScienteae, 8(3), 117-126.

Putra, T. P., Adyatma, S., \& Normlenai, E. (2016). Analisis perilaku masyarakat bantaran sungai martapura dalam aktivitas membuang sampah rumah tangga di kelurahan Basirih kecamatan Banjarmasin Barat. JPG (Jurnal Pendidikan Geografi), 3(6).

Purwanto, N. (2018). Perilaku Sadar Lingkungan Pemukim Bantaran Sungai jelai, Kabupaten Sukamara Environmental Conscious Behavior of Settler Jelai River Banks, Sumakamara District. Jurnal Pembangunan Wilayah dan Kota, 14(1), 41-50.

Priyono, E. A. (2001). KESADARAN HUKUM IVIASYARAKAT DI SEPANJANG SUNGAI SILANDAK TERHADAP UPAYA PENGELOLAAN RUNGS! LINGKUNGAN (Studi kasus di Kelurahan Purwoyoso Kec. Ngalian Kodya Semarang).

Razikin, P., Kumalawati, R., \& Arisanty, D (2017). Strategi Penangulangan Bencana Banjir Berdasarkan Persepsi Masyarakat Di Kecamatan Barabai Kabupaten Hulu Sungai Tengah. JPG (Jurnal Pendidikan Geografi),4(1).

Rismawati, L., Priatmadi, B. J., Hidayat, A. S., \& Indrayatie, E. R. (2020). Kajian Persepsi dan Perilaku Masyarakat Terhadap Pencemaran Air Sungai Martapura. EnviroScienteae, 16(3), 389-396

Yulida, N., Suwarni, A., \& Sarto, S. (2016). Perilaku masyarakat dalam membuang sampah di aliran sungai batang bakarek-karek Kota Padang Panjang Sumatera Barat. Berita Kedokteran Masyarakat, 32(10), 373-378. 